Alessandro Arienzo. Associate Professor in History of Political Thought at the Università degli Studi di Napoli “Federico II". He has published on early modern theories of Reason of State, on Machiavellianism and Counter-reformation political culture, in particular in the British context. He is also the author of several works on contemporary theories of global and European governance, on neo-liberal governmentality, and on precariat.

Contact: alessandro.arienzo@unina.it 


\title{
HUMAN SECURITY: SECURING ECONOMICS, POLITICS AND GOVERNANCE IN A GLOBALIZED WORLD
}

DOI: $10.17450 / 150204$

\author{
Alessandro Arienzo \\ Università degli Studi di Napoli, Federico II
}

Reception date $20^{\text {th }}$ September 2015; acceptance date $15^{\text {th }}$ October 2015. This article is developed within a project research held at the Dipartimento di Studi Umanistici, Università degli Studi di Napoli, Federico II.

\section{Abstract}

One of the more fascinating themes of the present debate about the role of the State in international relations is represented by the concept of human security. This concept was first introduced in the Human Development Report published in 1994 by the UNDP as one of the five pillars of a new "people-centred world order". In my contribution I will present the salient traits of theories of human security and security governance that operate on the foundation of proposals for global security in the official documents by UN, UNDP, OSCE in order to interprete human security as a part of a wider neo-liberal governmentality, putting both individuals and collectivities "at work" in a search for an economic self-governance.

\section{Keywords}

Human security, global governance, sovereignty, neoliberalism, international relations. 


\section{Resumen}

Uno de los temas más fascinantes del presente debate acerca del papel del Estado en las relaciones internacionales está representada por el concepto de la seguridad humana. Este concepto fue introducido por primera vez en el Informe sobre Desarrollo Humano publicado por el UNDP en 1994 como uno de los cinco pilares de un nuevo "orden mundial centrado en las personas". En mi intervención voy a presentar los rasgos sobresalientes de las teorías de la seguridad humana y la gestión de la seguridad que operan sobre la base de las propuestas de la seguridad global en los documentos oficiales de la ONU, el UNDP y la OSCE, a fin de interpretar la seguridad humana como parte de un contexto más amplio de la gubernamentalidad neoliberal colocando tanto individuos y colectividades "en el trabajo" en una búsqueda de una auto-gobernanza económica.

\section{Palabras clave}

Desarrollo humano, gobernanza mundial, soberanía, neoliberalismo, relaciones internacionales.

One of the more fascinating themes of the present debate about the role of the State in international relations is the concept of human security. It was first introduced in the Human Development Report published in 1994 by the United Nations Development Program (UNDP) as one of the five pillars of a new "people-centred world order". It was used to identify a new approach to security based on a two-fold conception of the term: "first, safety from chronic threats as hunger, disease and repression. And second, it means protection from sudden and hurtful disruptions in the patterns of daily life". ${ }^{2}$ Since then, it has developed within the new policy framework of human security governance.

Both the terms of security and governance are as much evocative as vague and ambiguous. The latter is among the most recurrent expressions in the documents written

1. UNDP, Human Development Report: New Dimension of Human Security, Oxford University Press, New York, 1994, ch. 2, p. 22. On the concept of human security, see: B. von Tigerstrom, Human Security and International Law. Prospects and Problems, Hart Publishing, Oxford-Portland, OR, 2007; G. Frerks - B. Klein Goldewijk (eds), Human Security and International Insecurity, Wageningen Academic Publishers, Wageningen, 2007; S. Tadjbakhsh - A.M. Chenoy, Human Security. Concepts and implications, Routledge, London-New York, 2007.

2. UNDP, Human Development Report, p. 22. 
by international agencies and institutions like the UN, the WTO, the World Bank, and the OECD used to designate a form, a style of governing that is different and alternative to that of centralised state government. ${ }^{3}$ This term is mostly understood to mean processes and structures of decision that cannot be traced back to the exercise of political sovereignty. The term of security is also a very unclear one. Typically associated in the international relation to the ideas of 'reason of State' and 'interests of the State', security is conceived as the fundamental aim of a political order meaning self-preservation and survival. In the early 1990s, the transformations in global politics that occurred following the fall of Cold War balance have produced profound and substantial changes in the theory and practices of international politics. In particular, the UN have set out document policies on support and recovery for States and distressed populations on the basis of this new concept of human security in which the idea of security was enlarged and widened to understand also individual and collective 'well-being' and human development.

These changes in discourses on international relation are not only significant for their analytical and normative implications in regard of the role of the State in global politics. Human security is, in fact, depicted as a conceptual framework within with the role of governments is somehow limited and intertwined in a complex network of international actors, being a policy response primarily aimed at implementing basic human rights on a world-wide scale. These changes are indicative of the political transformation fostered by the so-called 'globalization' on the relation between State-building and socio-economic development.

My interest is thus to investigate the relation between human security governance and the State as it is implied in current debate on human security. I will attempt to draft the central features of multiform policies, set to work by - and by means of - multiple actors, including the State, in order to bring about economic development, security and democratic government. As Paul Collier has pointed it out, human security may be interpreted as the attempt to respond to a wider 'political economy of conflict' being produced by a stronger international economic competition. ${ }^{4}$ I will focus on migration and global policies on recovery and support of displaced people so to highlight the role attributed to the global market and to economic actors. Lastly, I will briefly discuss

\footnotetext{
3. A.M. Kjaer, Governance, Polity Press, Cambridge, 2004. On the relation between governance and government see J.N. Rosenau - E.-O. Czempiel, Governance Without Government: Order and Change in World Politics, Cambridge University Press, Cambridge, 1992.

4. P. Collier, “The Market for Civil War”, in Foreign Policy, n. 136 (May-June), 2003, pp. 38-45; P. Collier - A. Hoeffler, Greed and Grievance in Civil War, World Bank, Washington DC, 2001.
} 
global security governance as an expression of a non-statal government over populations, which necessitates the strengthening both of statal institutions and of autonomous dynamics of the competitive market. In fact, the relation between human security as a framework and economic development has not received enough attention so far in current literature on human security.

\section{From security system reform to human security governance}

It was in the early 1980s that the Copenhagen School in International Relation developed an expanded theory of global security in which social aspects of this notion were emphasized. Their scholarly effort influenced the works of the the Brandt Commission which in 1983 proposed that:

security must be reconceived with people foremost in mind. The purely defensive concept of security should be enlarged to include hunger, disease, poverty, environmental stress, repression, and terrorism, all of which endanger human security as much as any military provocation. To that end, the international community has the responsibility to eliminate any social conditions that pose threats to the protection and dignity of people, before they erupt into armed conflict ${ }^{5}$.

This new agenda stimulated the reconsideration of civil-military relations, with the goal of promoting a definition of the security sector that can superannuate the mere subordination of the armed forces to regularly 'elected' civil leaders, as it was affirmed by the Copenhagen Document on the Human Dimension (1990). ${ }^{6}$ The aims of this document were the improvement of the efficacy of international interventions to guarantee the security of States, and the enlargement of spaces for the democratic control of the diverse institutions connected to the promotion of security. The Copenhagen document stressed the necessity to reorient the concept of security from the state to the individuals and their communities, and to broaden the nature of security threats beyond purely military ones.

5. J. B. Quilligan, The Brandt Equation: $21^{\text {st }}$ century blueprint for the new global economy, Brandt 21 Forum, 2002, available at www.brandt21 forum.info/BrandtEquation-19Sept04.pdf (last accessed 29 Oct. 2015).

6. Later followed by the Conference on Security and Cooperation in Europe (CSCE) held in the same year and by the Moscow Document on the Human Dimension (1991). 
It is along this debate that the United Nations Development Programme first proposed the concept in its 1994 Human Development Report. Quite optimistically, the UNDP predicted that "the idea of human security [...] is likely to revolutionize society in the $21^{\text {st }}$ century". According to this agency, security should include issues such as: political and economic development, individual and collective protection from political, ethnic and religious oppressions, from criminality and corruption, from poverty, illiteracy and disease as well as from natural calamities. In short, human security can be said to have two main aspects. It means, first, safety from such chronic threats as hunger, disease and repression. And second, it means protection from sudden and hurtful disruptions in the patterns of daily life - whether in homes, in jobs or in communities. ${ }^{8}$

The reasons for this change in international relations and in global governance approach to security were expressed in 2000 by the Secretary-General of the UN Kofi Annan who launched the 'Global Compact Initiative' stressing that peace and international security were placed in more danger from intra-statal conflicts than by conflicts between States. The weakness and the potential collapse of the State constituted dangers for regional and global security potentially greater than those represented by States endowed with an excessive military power. The same campaign also emphasised how an entire series of non-statal actors were now able to put at risk the security and good governance of States, and noted that the victims of the conflicts that have occurred in the post Cold War period have been constituted almost solely by civilians. Precisely in order to offer a response to these dramatic claims, the necessity of a collective security no longer focused on the security of States was proposed, a collective security that would be able to include a safety net for individuals, for their rights, and for their potentialities of development. Rethinking the concept of 'security' in international relations needed, nonetheless, the concomitant reshaping of the entire security sector.

In accordance to the indications given by the Secretary-General of the UN, a document written in 2001 by the Development Assistance Committee (DAC) of the Organization for Economic Cooperation and Development (OECD), entitled DAC Guidelines: Helping Prevent Violent Conflict, defined security as: an all-encompassing condition in which people and communities live in freedom, peace and safety, participate fully in the governance of their countries, enjoy the protection of fundamental rights, have access to resources and the basic necessities of life, and inhabit an environment which is not detrimental to their health and well-being. The security of people and the security of

7. UNDP, Human Development Report, p. 22.

8. Ibid. 
states are mutually reinforcing. A wide range of State institutions and other entities may be responsible for ensuring some aspect of security. ${ }^{9}$

On this basis, there was thus the need to begin a security system reform, understood as the affirmation of a 'security system' - which includes all the actors, their roles, responsibilities and actions - working together to manage and operate the system in a manner that is more consistent with democratic norms and sound principles of good governance, and thus contributes to a well-functioning security framework. ${ }^{10}$

Security system reform has thus represented an important turning point in the codification of security and of the role that statal institutions must play in order to guarantee it, opening up to a 'governance' oriented approach to security policies different from more traditional interstatal relations. These approaches shared a definition of security as a twofold condition of freedom: freedom from fear - a definition compatible with a State-centric and 'realist' perspective - and a broader idea of freedom from want. ${ }^{11}$ Despite that, this approach was strongly contested both for its excessive extension of factors relevant to a notion of security understood, at least on the international level, in more limited terms, and for having offered a merely negative definition of security.

Between 2000 and 2003, the concept has been therefore articulated around the two notions of 'responsibility to protect', adopted by the International Commission on Intervention and State Sovereignty (ICISS) under the authority of the Canadian Government, and 'responsibility for development', promoted by the Commission on Human Security (CHS), and by the Japanese minister Keizo Obuki. ${ }^{12}$ In fact, the document Human Security Now of 2003, written by the CHS and taken up by the UN, took into account and integrated both the proposals, affirming that human security "is concerned with safeguarding and expanding people's vital freedoms. It requires both shielding people from acute threats and empowering people to take charge of their own lives". ${ }^{3}$ The following years, the concept of human security assumed an even ampler meaning

9. OECD-DAC, The DAC Guidelines: Helping Prevent Violent Conflict, OECD Publishing, Paris, 2001, p. 38.

10. Ibid.

11. S. J. Maclean - D.R. Black - T.M. Shaw (eds), A Decade of Human Security, Global Governance and New Multilateralisms, Ashgate, Aldershot, 2006.

12. On these developments, see: R. Paris, "Human Security: Paradigm Shift or Hot Air", in International Security, 26, 2 , 2001, pp. 87-102; G. King - C.J.L. Murray, “Rethinking Human Security”, in Political Science Quarterly, 116, 4, 2001-2002, pp. 585-610; D. Henk, "Human Security: Relevance and Implications", in Parameters, 25, 2, Summer 2005, pp. 91-106. 13. Commission on Human Security (CHS), Human Security Now, New York, 2003, p. IV. Two important previous documents that anticipated these themes: DAC, Helping Prevent Violent Conflict, OECD Publishing, Paris, 2001, and DAC, Poverty Reductions, OECD Publishing, Paris, 2001. Also important it is the document "Security Issues And Development Co-Operation: A Conceptual Framework For Enhancing Policy Coherence", in The DAC Journal, 2, 3, 2001, pp. 33-71. 
when the UN itself endorsed it as a key component of 'human security' agenda begun in its programme of development.

On the contrary, the document Security System Reform and Governance, ${ }^{14}$ proposed in 2005 by the Development Assistance Committee of the OECD, framed the concept of security within the interventions of governments and of international institutions in contexts of crisis. Security was associated "to personal and State safety, access to social services and political processes. It is a core government responsibility, necessary for economic and social development and vital for the protection of human rights" ${ }^{15}$ As a notion, security appeared to be still strongly concentrated on the use of public resources for the guaranteeing of security of citizens. In this sense, it confirmed the centrality of statal institutions connected to such a function. Although it was precisely with it that began the discussion around the themes of the 'privatisation' of security and of developments inherent to the market of private security. However, the lines of intervention established by the OECD posed the necessity of States' favouring 'extensive' and structured policies of security not derivable solely from defence, intelligence and policing: "The overall objective of security system reform is to create a secure environment that is conducive to development, poverty reduction and democracy". ${ }^{16}$ A secure environment should in fact rest upon two essential pillars:

i) the ability of the State, through its development policy and programmes, to generate conditions that mitigate the vulnerabilities to which its people are exposed; and

ii) the ability of the State to use the range of policy instruments at its disposal to prevent or address security threats that affect society's well-being. ${ }^{17}$

Overall, the reforming of the security sector proposed by the OECD remained State-oriented. The State must be capable of utilising its own political and institutional resources in order to guarantee the affirmation of a broader understanding of security. The goal is nonetheless to promote a notion of security that is no longer centred on the recognition of external and internal enemies, but that occurs within a 'whole government approach', whose objectives are "[ to] foster interministerial dialogue, implement institutional change, and mainstream security as a public policy and governance issue". ${ }^{18}$ In order to do so, however, the participation of multiple actors in shaping a 'secure environment' is needed. Civil society, adequately supported by international programmes

\footnotetext{
14. OECD-DAC, Security System Reform and Governance, OECD Publishing, Paris, 2005, p. 11.

15. Ibid.

16. Ibid., p. 16.

17. Ibid., italics mine.

18. Ibid., p. 12.
} 
of cooperation and development, must, in fact, create and diffuse "a pro-reform environment for democratic governance" ${ }^{19}$ In this sense, the establishment of a democratic environment is held to be the result of the promotion of secure and economically productive areas. In this sense, Roland Paris believes that "the idea of human security is the glue that holds together a jumbled coalition of 'middle power' States, development agencies, and NGOs - all of which seek to shift attention and resources away from conventional security issues and toward goals that have traditionally fallen under the rubric of international development" ${ }^{20}$

The 2003 report Human Security Now, however, already clarified the reasons why the reform of sectors connected to security was an integral part, but not exhaustive, of a more complex human security. The security measures implemented by States and by international organisms had to be backed up by a set of different policies centred on the a variety of socio-economic players, among them the State. This raises the issue of the convergence of different spatialities. In fact, while the measure implemented by States must take place within a specific territory, policies activated by global institutions or network of actors may operate in narrower as well as broader territorialies. These networks, that have to support and promote institutional measures eventually adopted by single States, may not have a determinate territorial basis. On the contrary, these may take place in the 'interstices' between States and non-State spatialities as they are composed by different institutions, agencies and social actors that operate on the global, regional or local level.

Certainly, if "security and development are increasingly seen as being inextricably linked", it thus becomes necessary "to mainstream security as a public policy and governance issue". ${ }^{21}$ It is precisely due to this that the report Human Security Now emphasised the complementarity between human security and security of the State. In particular, it emphasised the necessity of favouring the care of individuals and of communities in a context that does not contemplate in an exclusive fashion threats comprehended as dangers for security: "achieving human security includes not just protecting people but also empowering people to fend for themselves" ${ }^{22}$ For such an end, "the range of actors is expanded beyond the State alone". ${ }^{23}$ The security of the State is no longer, therefore, the predominant target of security and the State is no longer the key actor. Rather, it may

\footnotetext{
19. Ibid., p. 16.

20. R. Paris, Human Security, p. 88.

21. OECD-DAC, Security System Reform and Governance, p. 16.

22. CHS, Human Security Now, p. 4.

23. Ibid, p. 52.
} 
constitute an instrument, albeit necessary, for guaranteeing the promotion of democratic freedoms and the development of a competitive market on regional scales.

\section{On human security governance}

From being a category articulated prevalently around the necessities of self-preservation of the State, security, thus, come to be interpreted as a human security. The reasons for this transformation are multiple. The permanent conflictuality of the so-called Cold War, whose strongly ideological traits characterised the multiplication of internal wars in the context of a relatively stable international order, has been substituted by an incoherent and multiform intertwining of wars between States, international police operations, preventative aggressions, humanitarian crises, terrorisms and national and global resistances. The military equilibrium between the super powers, which even gave some form and a direction to the dispersed instances of conflict in the world, has fallen, thus liberating energises and tensions to which it appears to be difficult today to give a single meaning. Moreover, the new tensions driven by environmental calamity and by economic crisis needed for a different representation of the international order.

Thus, if security was understood and practiced as national security and defined in military terms during the Cold War, the proliferation in the last two decades of threats, emergencies and risks favoured the progressive amplification of the concept. As Heiner Hänggi observed: "It was increasingly noted that security might be endangered by more than military threats alone, which led to the inclusion of political, economic, societal and environmental aspects". Moreover, he also noted that "there is a growing recognition that in the age of globalization, and with the proliferation of internal wars and 'failed States', individual and collectives other than the State could, and indeed should, be the object of security". ${ }^{24}$

These processes fostered a double transformation in the approach to the theme of security. In the first place, there was the elaboration of a new politics of security, described as security sector reform, which has put in discussion both the strictly statal defensive interpretation of security and also the centrality attributed to the public-statal actors, particularly the army and the police. If both the statal institutions as well as those structures whose primary function is to protect society have traditionally been ascribed

24. H. Hänggi, "Making Sense of Security Sector Governance”, in H. Hänggi - T.H. Winkler (eds.), Challenges of Security Sector Governance, LIT Verlag, Münster, 2003, p. 6. 
to the level of security, the expression security sector instead attempted to expand its goals and methods from the usual military environment to include public security and individual security from crime, disorder and violence. In the second place, in the context of the new security agenda, the notions of security and of development are shown to be interdependent. Security was no longer related in exclusive terms to the level of statal defence of its own order or the level of the security of the population faced by pressing and imminent threats. It was also associated to processes of growth and of economic-social development that, while based on policies of promotion and of individual and collective defence from immediate threats, should contribute to the strengthening of the State and the care of populations.

Security developed in human security by including in a single nexus two different approaches:

a) the first, which we can call security-preservation, includes the most common reflection on the defence of the State and of the nation from the external and internal enemy. A particular tension is also assumed in this case, a tension that is relative to the strengthening of the statal institutions by means of processes of international governance (of help and support) and of State-building.

b) the second can be defined as security-development. This is the security related to intervention on populations, on their productive and self-reproductive potentialities. It is the more complex human security that, theorised by the UN, explicitly underwrites the proposals of global security governance. It prefigures, alongside processes of State-building, paths of market-building and of 'activation' of a potent civil society.

The first approach includes both that range of instruments at the disposition of the State - the ordinary and extraordinary constitutional provisions, the army, the intelligence services - that aim to guarantee the preservation of the political stability faced by pressing threats, and also the processes of institutional, bureaucratic and administrative construction that tend to configure a stable, efficient and democratic statal architecture. The second approach, on the other hand, includes those dispositifs that aim to promote a certain economic and social development, in such a way as to constitute not so much the objective of processes of political and institutional stabilisation, as in the past, but their precondition. 
This twofold strategy of security is only partially concerned with States and borders, as it aims at governing populations and individuals according to a project of socio-economic strengthening and development centred on a democratic and (neo)liberal political model. However, this strategy cannot, and does not want, to reduce the State to an instrument of order and of containment of conflicts and of populations. On the one side, the strengthening of the State - through policies of State-building - is a necessary tool for any socio-economic development. On the other side, the strengthening of the State and of its institutions depends on the promotion of the well being and on the economic development of a population. In situations in which a State does not exist or, though existing formally, is not able to guarantee any security, the model activated by human security imply that the global market society and its actors have to take the lead of any process of State-building and recovery. The global market and the global civil society may offer that political legitimacy and the consensus missing in weak or failed institutions.

Recent reflections on security governance derive from the failure of traditional policies of peace-building, and from the evident limits of programmes of peace-enforcing. In this sense, Antonio Franceschet argued that human security is a concept that can be made intelligible by "the politics of applying law and legalism to global politics", and that "it has been applied and implemented [...] primarily through legalistic initiatives". ${ }^{25}$ This is certainly true in many cases. However, as I will briefly discuss by focusing on the connexion between migration, population and development, it is deemed the networks of regulative power and of international organisms to promote the construction of a market economy. Moreover, by means of this, to favour the emergence of a civil society and to offer the legitimacy necessary for the formation of a firm statal authority. In other words, only the correct functioning of the market and of the autonomous flows of international civil society can give birth to processes (often diversely intended) of statal and territorial stabilisation.

\section{Populations, migrations, development}

Security governance shapes a set of policies that intervene in the most diverse aspects of human life. These policies find application on local, regional, and global levels

25. A. Franceschet, "Global legalism and Human Security", in S.J. Maclean - D.R. Black - T.M. Shaw (eds.), A Decade of Human Security, p. 31. 
by intervening on individuals and on populations. Certainly, themes such as the control and administration of birthrates and mortality, the proliferation of conflicts and wars, the struggles against epidemics, famine, new diseases, poverty and scarcity of resources, posit the exercise of a specific governmentality - or biopolitics - at the centre of these policies.

This governmentality has as its object not only the States, nor simply individuals, but populations, although the individual remains the social unity of reference. The individual appears as the holder of basic human rights and is at the basis of processes of construction of the democratic-representative political architecture. These processes represents procedures of empowerment and democratization. Yet when security intervenes as a guarantee of safety or of development, it does so because of a profoundly different logic of government. This logic affects population as an 'aggregate body' and as a set of processes and phenomena to be appropriately managed.

In this context, the territorial dimension shows its importance as a principle of separation and spatial division that is necessary for the localisation of security interventions. ${ }^{26}$ Indeed, processes of State-building and market-building that underlie policies of global security governance can have a positive outcome only if they guarantee socio-economic stabilisation and institutional localization. Nonetheless, in the human security approach to global crisis the existence of an indissoluble relation between State and territory is no longer the precondition for the existence of sovereign political order. On the contrary, it is the construction of a sovereign order that may becomes the object of territorialized policies. In this sense, control and management of migrations, the containment of phenomena like movement and de-localisation of populations due to environmental or military crises, represent the principal testing ground of these policies, as they lie at the crossroad of all these problems. ${ }^{27}$ Discourses around security, when they are applied to these phenomena, are perhaps those that help us to understand the logic of the governance of populations that underlies contemporary reflections on human security and the role that they attribute to the State.

The logic of governing the phenomenon of migration follows the lines of promoting foreseeable and ordered movements through concerted and multilateral policies of global governance of migrations: "Multilateral approaches are essential for promoting orderly and predictable movements of people. Needed is an international migration framework of norms, processes and institutional arrangements to ensure such order

26. S. Mezzadra - B. Neilson, Border as Method, or the Multiplication of Labor, Duke University Press, Durham, 2013. 27. D. Graham (ed.), Migration, Globalisation and Human Security, Routledge, London, 1999. 
and predictability". ${ }^{28}$ Order and predictability are, in these cases, verifiable objectives only based on the efficacy of territorial intervention of implemented policies. These policies certainly exist due to the contribution of several actors, but they still attribute a central role to statal authorities. It is precisely the necessity of control and territorial management of phenomena, fluid in their own nature, which pushes towards concerted policies and toward the strengthening of territorial divisions. This is because "to identify and implement solutions to displacement situations [...] through voluntary repatriation, resettlement or integration into host communities" 29 implies an effort by the international community to reinforce territorial control and government of populations, exercised by State institutions with the support of supranational actors and policies.

In this sense, the change that has occurred in the last decades regarding support policies for refugees is significant. While refugees were previously 'taken care of' by welcoming policies shaped on the principle of an individual right to find refuge in the host country - a policy with a juridical matrix, which is focused upon the individual as the bearer of inalienable rights - the refugee is today 'taken care of' by security policies that provide assistance and support to repatriation, but also forced mobilisation, of populations. ${ }^{30}$ These policies are supported by humanitarian intervention which is offered by the networks of organisations and international agencies, and that are implemented by resorting - when necessary - to the usage of force by States. The State is therefore confirmed both as the holder of a monopoly of the usage of legitimate violence and as the holder of a monopoly upon the legitimate circulation of commodities and people. ${ }^{31}$ However, at least in the latter case, the regulation of processes and the management of fallouts produced by this regulation are undertaken by international security 'agents'. In this light, the pronouncement of the High Commission of the United Nations for refugees in its Hague Program of 2004 is significant. ${ }^{32}$ It maintained "an increasing externalisation of tools and measures of control of migrations, even of those aiming to make policies of repatriation more effective". ${ }^{33}$ Instead of structuring interventions on the basis of individual rights, the eventual attribution of which remains among the competences of territorial sovereignties, security governance tries to define a migration

28. CHS, Human Security Now, p. 52.

29. Ibid.

30. On this theme, see: H. Adelman, "From Refugees to Forced Migration: the UNHCR and Human Security", in International Migration Review, 35, 1, 2001, pp. 7-32.

31. J. Torpey, The Invention of the Passport. Surveillance, Citizenship and the State, Cambridge University Press, Cambridge, 2000.

32. Presidency Conclusions, $4-5^{\text {th }}$ November $2004-14292 / 04$ Annex I.

33. E. Rigo, "Pratiche di cittadinanza e governo della circolazione nello spazio europeo", in A. Vinale (ed.), Biopolitica e democrazia, Mimesis, Milano-Udine, 2008, p. 291. 
framework within which these moves can be played out and their containment and protection can be offered. Certainly, this framework will be able to work only by means of States and beyond them, since migrations and movements of people, whose dimension is irreducible to territorial divisions, make de-territorialised policies necessary, alongside strongly territorialising policies. Without a clear territorial dimension, it appears to be difficult to build a system capable of individuating in time the risks that relate to these phenomena and to operate in order to restrain situations of worse disadvantage: "The security risks arising during large-scale forced population movements need to be acknowledged and better understood [...] Given the permeability of borders and the ease of travel, efforts to strengthen the refugee regime and establish and international migration framework need to be accompanied by improvements in the protection of the internally displaced persons" ${ }^{34}$

Security governance, therefore, is exercised by attempting to prevent, to anticipate and to govern the crisis in consideration of the ineliminable facts that are offered by migration impulses, by the fallibility of policies of repression or by the mere containment of migrations. In this context, development and economic promotion policies assume a prevalent and determinant role, in a double sense: on the one hand, the construction of a market society promotes wealth and economic development, thus slowing down the most dramatic reasons for the movements of populations and favouring a migration that is linked to aspirations instead of necessities. On the other hand, the promotion of regulated and ordered movements of people across the borders, "reinforces the interdependence of countries and communities and enhances diversity. It facilitates the transfer of skills and knowledge. It stimulates economic growth and development". ${ }^{35}$ The link between development and migration is certainly complex: if natural fluctuations of markets and the unavoidable phases of economic crisis can push people to emigrate, it is also true that most of the movements that are directed towards the richest countries come from middle-income countries. This occurs because "research also shows that poverty reduction strategies may contribute to increased movements of people in the short and medium terms because people have access more to the money, information and networks that are essential for moving from one country to another".36

Migratory policies are, thus, closely linked both to demographic dimensions and to dimensions of control of resources (human and environmental) as well as to di-

34. CHS, Human Security Now, p. 52.

35. Ibid., p. 41.

36. Ibid., p. 44. 
mensions of the economy and the market. Franck Düvell has emphasised how the current policies are articulated beginning from needs of the labour market and how they compose a global regime of government of 'hybrid' migrations, in which States, post-national formations and new global actors such as the International Organisation for Migration or the multiple NGOs that intervene in this theme. ${ }^{37}$ In the section of Human Security Now entitled Economic security - the power to choose among opportunities, as well as in the document A Development Co-operation Lens on Terrorism Prevention, the connection between security and development is also evoked in order to respond to the fears provoked by an international terrorism that is favoured by these movements of people and populations. Migration data, and in more general terms movements of populations and people, assume a very particular importance within the framework of security policies. This happens because these movements, more than other phenomena, reveal the deep insecurity that characterise the condition of the planet. It is possible to address this condition only by defining 'structural' and long-term policies. For this reason, both documents strongly stressed the necessity of programmes to structure the relation between governments, donors, and all those actors who are involved in the processes of prevention of conflicts and of support for development. At the same time, the necessity of strengthening governance by means of policies that encourage the correct development of difficult areas is re-emphasised. In other words, "the key issue is how to establish a democratic political order, buttressed by social and economic growth" ${ }^{38}$

The governmental logic that gives shape to the specific practices of government of security governance is thus the expression of the efforts to redefine the relations between State and the global civil society as an agent of economic development. In this sense, what Michel Foucault wrote in his 1978 course on biopolitics seems to be confirmed: namely, that what was specifically at stake in the liberalism that developed from the 1930s until contemporary neo-liberalism is "how the overall exercise of political power can be modeled on the principles of a market economy" ${ }^{39}$ Security governance shows how the global exercise of a certain type of political power is based upon principles of regulation of the economic system. In this sense, today a new and very particular

37. F. Düvell, "La globalizzazione del controllo delle migrazioni", in S. Mezzadra (ed.), I confini della liberta. Per un'analisi politica delle migrazioni contemporanee, DeriveApprodi, Roma, 2004, pp. 23-50. See also Sandro Mezzadra's Introduction to the volume: Capitalismo, migrazioni e lotte sociali. Appunti per una teoria dell'autonomia delle migrazioni, pp. 7-19.

38. CHS, Human Security Now, pp. 67-68, italics mine.

39. M. Foucault, The Birth of Biopolitics. Lectures at the Collège de France 1978-1979, Palgrave-Macmillan, London, 2008, p. 131. 
intertwining between macro- and micro-economic paradigms would seem to confirm the foucauldian thesis of a liberal system that composes an:

[...] economic and social regime in which the enterprise is not just an institution but a way of behaving in the economic field - in the form of competition in terms of plans and projects, and with objectives, tactics, and so forth - you can see that the more the law in this enterprise society allows individuals the possibility of behaving as they wish in the form of free enterprise, and the greater the development of multiple and dynamic forms typical of this "enterprise" unit $[\ldots]^{40}$

The taking of distance from the pure model of the vertical exercise of government security is perhaps one of the characterising elements of contemporary reflections on global governance. Additionally, it seems indicative of the crisis of liberal governmentality; a crisis that could be referred to the increase of the economic cost of the exercise of freedom. The foucauldian thesis is particularly important precisely because it ties the crisis in the form of liberal governmentality to the contextual promotion of freedom, and, it reveals the relation between security policies and the government of the population.

Human security represents an effort to activate pro-social behaviours. It is in the attempt of building a complex of inter-individual and collective pro-social relations that we find the profound reason for the emergence of a security governance that aims to structure a new relation between the State and non-State actors, although within the limits that are imposed by the equilibrium between economic development, security dispositifs, and representative democracy. Economic development of the market and democratic political order thus compose a system of verification - the principle upon which the results reached by security governance policies can be verified. Therefore, security, development, and population are perhaps the terms that more than others mark how the processes of transformation of current liberal governmentality express a "critical" moment of acceleration and systemic change. On the one hand, there is the will to see the political democratic model affirmed on a global scale; on the other hand, there is the attempt to support this model by means of policies of governance that empty the representative dimension and reduce the space of the exercise of government. In similar terms, there is therefore the attempt to favour autonomous

40. Ibid., p. 175. 
developments of a competitive market through regulative policies that, however, must be supported by dispositifs of security because the conservation and the increase, on a global level, of prevalent power structures need the enlargement of the liberal political space and of the market.

\section{Conclusions}

The 1994 document launched by the UN offered a conception of human security in many ways different from the notion of 'security of the individual', conceived both in the current fashionable neoliberal sense and in the most typical liberal notions of competitive and possessive individual. Since then, the 'failure of the State' has resulted in the pursuit of human security through the informal sector, beyond the reach of the formal institution of the State, and through the development of complex networks of diverse players acting on multilevel spatial and institutional dimensions. In 1995 the UN set a target of a 50 per cent reduction in the number of people existing in absolute poverty in 2015, and Caroline Thomas sharply observed that this outcome was "to be delivered not by any redistributive mechanism, but rather by the application of the particular neoliberal model of development promoted in the 1980s and 1990s by global governance institutions". ${ }^{41}$

Human security governance thus refers to liberal democracy as to the political framework for global politics, although the institutional model is shifted from 'people representation' and 'nation-State sovereignty' to a more complex and ambiguous 'Government plus Governance' system. In dealing with failed or quasi-failed States, the weakness of State institutions is compensated for by transnational networks of support, processes of political or economic localisation/delocalisation, or of re-allocation on a macro-regional or global scale of decision-making processes. Within this approach, the State remains, on the global level, the unity of measure of political spaces by guaranteeing those territorial divisions from which the organisation, prediction, intervention upon movements (of men or commodities) and management of flows begins. In this sense, security governance may well strengthen and attenuate the role of the State according to the context and the situations. Individuals and populations are the targets of

41. C. Thomas, "Global Governance, Development and Human Security: Exploring the Links", in Third World Quartely, 22, 2, 2001, p. 160. See also: C. Thomas, “Where is the Third World Now?”, in Review of International Studies, 25, 1999, pp. 225-244; C. Thomas, Global Governance, Development and Human Security: The Challenge of Poverty and Inequality, Pluto Press, London, 2000. 
new governmental practices exercised on a local and global scale, which, although they transcend the State, exploit its sovereign dimension in order to guarantee the continuity of those processes of political individualisation that we call citizenship. Security governance and human security governance precisely intervene in those contexts where the cores of State-political power are weaker, but the possibility to build a political-State order, based on market and civil society principles, is greater. In these areas, the construction of concurrential and competitive open markets is the base of human development and of the construction of pluralist democracy.

Human security thus poses the problem of a 'non-statal' government of populations at the centre of the reform efforts of the international organisations - a reform which is realised means of policies of territorial State-building and market-building, and by means of policies that support transnational networks of collective actors and regulative powers. In this sense, human security seems to activate two types of processes: the first can be referred to as policies of construction and reinforcement of statal institutions; the second aims to promote productive relations that can favour the birth of an efficient and competitive market. In the opening scene of this emerging human security governance, the themes of development and of democracy constitute the fulcrum around which it seems possible to create a pro-market and pro-social global environment that can be very broadly labelled 'neo-liberal'. When human security fails, nonetheless, traditional security policies - from diplomacy to military action - will take the lead. 